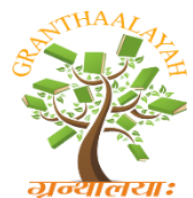

INTERNATIONAL JOURNAL OF RESEARCH GRANTHAALAYAH A knowledge Repository

Science

\title{
THE CORRELATION OF CARAPACE WIDTH - BODY WEIGHT, CONDITION FACTOR, AND ABUNDANCE OF SCYLLA SERRATA FORSSKÅL, 1775 IN EMBANKMENT LANE SILVOFISHERY DEVELOPMENT AREA OF MAROS DISTRICT
}

\author{
Budiman Yunus ${ }^{* 1}$, Suwarni ${ }^{1}$ \\ ${ }^{1}$ Faculty of Marine Science and Fisheries, Hasanuddin University, Indonesia
}

\begin{abstract}
The research aims to find out the correlation of carapace width - weight, condition factor and abundance of mangrove crab based on observation time and sex in the coastal waters of Maros district, South Sulawesi. This research provides information on the pattern of growth and chubbiness of mangrove crabs and its abundance in the coastal area of Maros district, South Sulawesi. The study was conducted from early February until the end of April 2019. Sampling was conducted on the coastal area of Kuri Lompo and estuary of Maros which is an integrated mangrove pond development (silvofishery). 213 mangrove crabs (120 male and 93 female) obtained from fishermen were measured. The coefficient $b$ of male and female mangrove crabs in February and March were 3.3626 and 2.6674, respectively. In April, b value of male and female mangrove crab was 3.5965 and 2.6506, respectively. This relation shows the growth type for males is allometric-positive whereas for females is allometric-negative. In April also saw the same growth coefficient in the previous month allometric positive for males and allometric negative for females. In general, the condition factor of male mangrove crabs in February and March is greater than female mangrove crabs. While, in April the condition factor of female mangrove crab is greater than male mangrove crab. The nature of condition factor of mangrove crab represents the distribution of crab abundance in the embankment lane silvofishery development area of 0.015 ind. $/ \mathrm{m}^{2}$.
\end{abstract}

Keywords: Mangrove Crab; Correlation of Carapace Width - Weight; Condition Factor; Abundance; Silvofishery; Coastal.

Cite This Article: Budiman Yunus, and Suwarni. (2019). "THE CORRELATION OF CARAPACE WIDTH - BODY WEIGHT, CONDITION FACTOR, AND ABUNDANCE OF SCYLLA SERRATA FORSSKÅL, 1775 IN EMBANKMENT LANE SILVOFISHERY DEVELOPMENT AREA OF MAROS DISTRICT." International Journal of Research - Granthaalayah, 7(12), 177-188. https://doi.org/10.29121/granthaalayah.v7.i12.2019.310. 


\section{Introduction}

Mangrove crab (Scylla serrata Forsskål, 1775) is one of the most valuable economical fisheries commodities in Indonesia. It has been known for its delicious and high nutritious meat flavor. Based on the result of proximate analysis, it is known that the meat of mangrove crab contains protein $44.85-50.58 \%$, fat $10.52-13.08 \%$ and energy $3.579-3.724 \mathrm{kcal} / \mathrm{g}$. In addition, it contains a variety of important nutrients such as minerals and omega-3 fatty acids. Also, crabs as a source of protein, folate, potassium, vitamin B12, phosphorus, and selenium (Karim, 2013). During this, demand for mangrove crab tends to increase every year, both from domestic and abroad. This causes an increase in the exploitation of mangrove crab in nature. Based on statistical data from the Department of Marine and Fishery of South-Sulawesi Province (2015), the production of mangrove crab catch in Makassar has fluctuated during the last 5 years.

In 2010, the production of mangrove crab catches reached 135.2 tons, in 2011 decreased 104.8 tons, in 2012 increased by 7.3 tons, in 2013 decreased by 8.5 tons, and 2014 decreased by 17.9 tons. The coastal area of Kuri Lompo and Maros estuary which bordered directly with Makassar strait is one of the most important waters because it is directly related to various aspects of community life, including as a fishpond and fishing area that directly adjacent to the mangrove ecosystem development area. Mangrove crab is one of the biota that is utilized by the surrounding community as a source of income and food. By looking at the phenomenon of increasing use of mangrove crab, it is necessary management that pays attention to the sustainable potential of mangrove crab in order to avoid extinction. One factor that supports the management is the availability of information about biological aspects of mangrove crab. Therefore, a research on the correlation of carapace width - weight, condition factor and abundance of mangrove crab especially in around the coastal area of sivofishery development of Kuri Lompo to Maros estuary are needed. This research aims to find out the correlation of carapace width - weight, condition factor and abundance of mangrove crab based on observation time and sex. While, the usefulness of research are to provides information about the pattern of growth and chubbiness of mangrove crabs in coastal waters of Kuri Lompo and Maros estuary.

\section{Method of Research}

\subsection{Time and Location}

The research was conducted from early February until the end of April 2019. Sampling was conducted around the waters between Kuri Lompo until Maros estuary, Maros district, South Sulawesi (Figure 4). The location of sampling is silvofishery development area about $2.3 \mathrm{Ha}$ $\left(23000 \mathrm{~m}^{2}\right)$. Sample analysis was conducted at Biology Laboratory of Fisheries, Department of Fishery, Faculty of Marine Science and Fishery, Hasanuddin University, Makassar. 


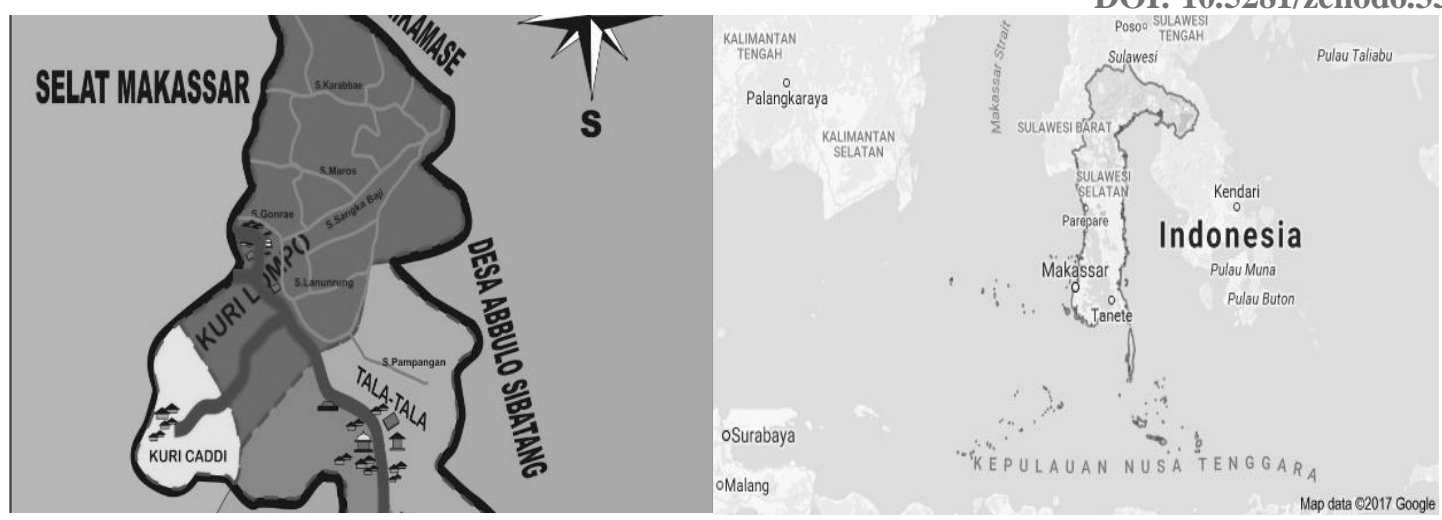

Figure 1: Map of Kuri Lompo in Makassar Strait

\subsection{Tools and Materials}

The tools used in this research were fishing gear bubu serves to catchs crabs, plastic bags for storing sample, preparatory boards for placing samples, sliding compass for measuring carapace width of crabs, digital scale $0.001 \mathrm{~g}$ to measure sample weights, and a camera for documentation. The sample used in this research is mangrove crab (Scylla serrata).

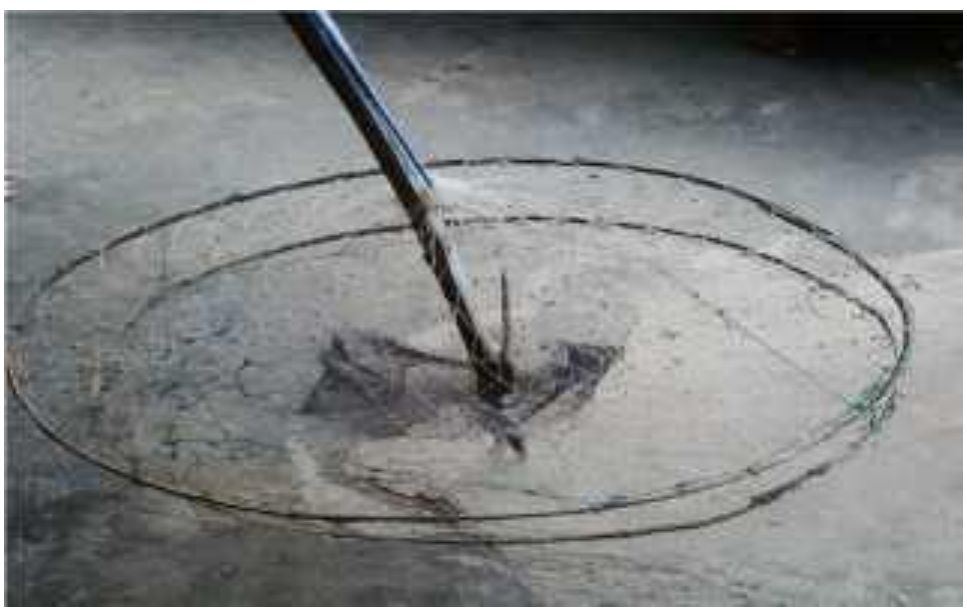

Figure 2. Fishing gear $b u b u$

\subsection{Sampling}

Sampling was obtained from the catch of fishermen operating around the waters of Kuri Lompo and Maros estuary. The fishing gear used is bubu. Sampling is done at intervals once a week. After the sample is collected, then put into a plastic bag which is then transferred to the laboratory to measure the carapace width and body weight. According to Rachmawati (2009), carapace width $(L)$ is the distance between the last marginal end on the left with the last right horizontal spine (horizontal), carapace length $(P)$ is the distance between the spine edge of frontal margin and the lower edge of carapace, while carapace height $(T)$ is the length of perpendicular line between the carapace and the abdomen (Figure 6). For carapace width was measured using a sliding compass $0.1 \mathrm{~mm}$ in accurate, while carapace weight using a digital scales 0.001 gram in accurate. 


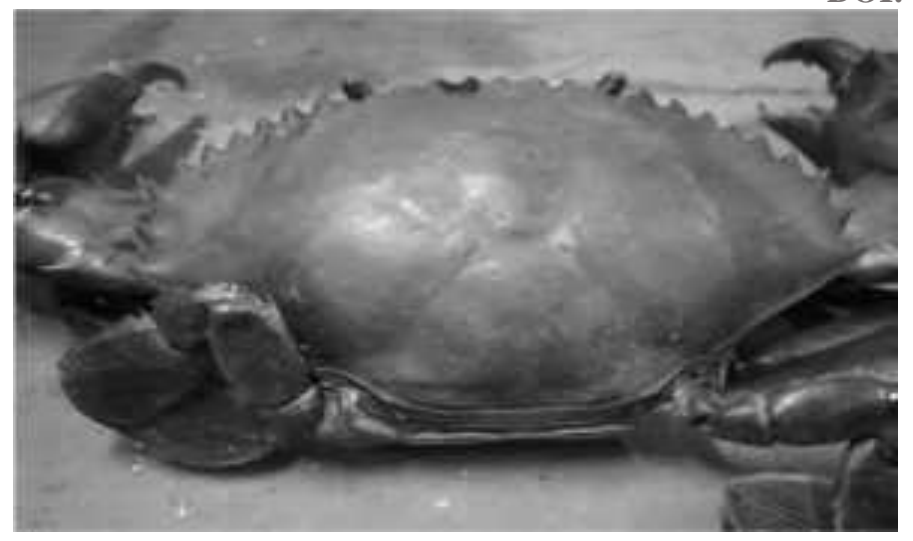

Figure 3: Measurement method; carapace width (1) and carapace length (2) of Scylla serrate

Determination of mangrove crab sexual is done by observing the shape of abdomen. The abdominal segment of male crab is tapered, while the female is wider. Female abdomen like stupa while male like pillar.

\section{Data Analysis}

\subsection{Correlation of Carapace Width and Weight}

To find the correlation of carapace width and weight of mangrove crab, we used Le Cren' (1951) equation in Sentosa and Sham (2011), i.e $\mathrm{W}=\mathrm{a} \mathrm{L} \mathrm{L}^{\mathrm{b}}, W=$ weight $(\mathrm{g}), L=$ carapace width (mm), $a$ and $b$ are constants. Correlation analysis shows the constant $(b)$, i.e the price indicating the growth pattern of the crab. If the constant value $(b=3)$ then its growth is isometric, the growth of length is equal to the growth of weight, whereas if the constant value (b > 3), then its growth is allometricpositive, the weight gain is faster than the length, and if the constant value $(b<3)$, then its growth is allometric-negative, the growth of length is faster than the growth of weight (Effendie, 2002). To test the regression coefficients, $\mathrm{b}=3$ or not, then $t$-test is performed with the following equation: $t_{\text {count }}=(3-b) / s b$ (Walpole, 1982 in Andy Omar, 2014). If the value of $t_{\text {count }}$ is greater than $\mathrm{t}_{\text {table, then }} b$ differs from 3 , if otherwise, then $b$ equals 3. Furthermore, statistical tests of regression coefficients on male and female crabs are performed. Then, the data obtained is processed using Microsoft Excel program.

\subsection{Condition Factor}

Calculation of condition factor for crabs whose growth is isometric, using the formula of Fulton (1904) in Sentosa and Sham (2011), i.e: $\mathrm{K}=(100 \mathrm{~W}) / \mathrm{L}^{3}, \mathrm{~K}=$ Condition factor, $\mathrm{W}=$ Weight (g) and $\mathrm{L}=(\mathrm{cm})$. Since the carapace width is measured in millimeters, W x 105 (100000). If the growth pattern is allometric, then the condition factor is calculated by using the relative condition factor which has the following equation:

$\mathrm{Kn}=\mathrm{W} / \mathrm{W}^{*}$ (Fulton 1904 in Sentosa and Sham, 2011)

$\mathrm{Kn}=$ Relative condition factor

$\mathrm{W}=$ Body weight of observation $(\mathrm{g})$ and

$\mathrm{W}^{*}=$ Predicted body weight through the equation of width-weight $\left(\mathrm{W}=\mathrm{aL}^{\mathrm{b}}\right)$ 


\subsection{Abundance}

Abundance of Scylla serrata was calculated based on Shannon-Wiener' formula (Odum, 1993), namely:

$\mathrm{K}=\mathrm{ni} / \mathrm{A}$

Where;

$\mathrm{K}=$ Density of organism species (number of individuals $/ \mathrm{m}^{2}$ )

$\mathrm{ni}=$ total number of individuals of species (individual)

$\mathrm{A}=$ Development area (silvofishery) $(2.7 \mathrm{Ha})$

\section{Results and Discussion}

\subsection{Correlation of Carapace Width and Body Weight}

In this research, total mangrove crabs analyzed were 136 i.e 80 males and 56 females. Statistical analysis of the correlation of carapace width to body weight can be seen in Table 2. As Table 2, it is seen that male crabs in February have an amount equal to that of females, which is 39 . $b$-value for male crabs is 3.3626 while female is 2.6674 . T-test analysis showed that male crabs have an isometric growth type; the increase in the carapace width is equal to the body weight, whereas the female crab has a allometric-negative growth type; the increase of the carapace width is faster than the weight gain. The value of correlation coefficient $(r)$ for the male mangrove crab equation is 0.9357 indicates strong correlation and for female is 0.5859 indicates moderate correlation (Table 2). This is in accordance with Andy Omar (2009) that if the value of correlation coefficient is 0.400.69 , then indicates a moderate correlation, whereas if the value of correlation coefficient is 0.70 0.89 indicates strong correlation. The graph of the correlation of carapace width and body weight of male and female mangrove crabs is presented in Figure 4.

Table 2: Analysis result of carapace width and body weights of male and female mangrove crabs

(Scylla serrata Forsskål, 1775) in February - April in the coastal waters of Kuri Lompo and Maros estuary

\begin{tabular}{|c|c|c|c|c|}
\hline \multirow[t]{2}{*}{ Parameter } & \multicolumn{2}{|c|}{ February - March } & \multicolumn{2}{|l|}{ April } \\
\hline & Male & Female & Male & Female \\
\hline Number of crab samples & 59 & 57 & 61 & 36 \\
\hline $\begin{array}{l}\text { Ranges of total width } \\
(\mathrm{mm})\end{array}$ & $76,5-137$ & $75-140$ & $72,5-135$ & $82,5-124,5$ \\
\hline $\begin{array}{l}\text { Average of total width } \\
(\mathrm{mm})\end{array}$ & 101,8462 & 101,4615 & 94,0732 & 92,2941 \\
\hline $\begin{array}{l}\text { Ranges of body weight } \\
\text { (g) }\end{array}$ & $60,84-489,37$ & $53,57-399,27$ & $46,35-460,72$ & $\begin{array}{l}57,17- \\
224,52\end{array}$ \\
\hline $\begin{array}{l}\text { Average of body weight } \\
(\mathrm{g})\end{array}$ & 193,4885 & 161,9387 & 149,0315 & 117,6635 \\
\hline $\log a$ & $-4,5005$ & $-3,1628$ & $-4,9758$ & $-3,1678$ \\
\hline $\mathrm{a}$ & 0,0000031 & 0,000687 & 0,00001 & 0,000679 \\
\hline
\end{tabular}




\begin{tabular}{|c|c|c|c|c|}
\hline $\begin{array}{l}\text { Regression coefficient } \\
\text { (b) }\end{array}$ & 3,3626 & 2,6674 & 3,5965 & 2,6506 \\
\hline $\begin{array}{l}\text { Correlation coefficient } \\
(\mathrm{r})\end{array}$ & 0,9357 & 0,5859 & 0,5004 & 0,4853 \\
\hline Regression & $\begin{array}{c}3,3626 \\
\mathrm{~W}=0,000031 \mathrm{~L}\end{array}$ & $\begin{array}{c}2,6674 \\
W=0,000687 \mathrm{~L}\end{array}$ & $\begin{array}{c}3.5965 \\
W=0,00001 \mathrm{~L}\end{array}$ & $\begin{array}{c}2.6506 \\
W=0,000679 \mathrm{~L}\end{array}$ \\
\hline$t$-test & $\mathrm{t}_{\text {cou. }}<\mathrm{t}_{\mathrm{tab}}$ & $\mathrm{t}_{\text {cou. }}>\mathrm{t}_{\text {table }}$ & $t_{\text {cou. }}>t_{\text {table }}$ & $\mathrm{t}_{\text {cou. }}<\mathrm{t}_{\text {table }}$ \\
\hline Growth type & $\begin{array}{l}\text { Allometric- } \\
\text { positive }\end{array}$ & $\begin{array}{l}\text { Allometric- } \\
\text { negative }\end{array}$ & $\begin{array}{l}\text { Allometric- } \\
\text { positive }\end{array}$ & $\begin{array}{l}\text { Allometric- } \\
\text { negative }\end{array}$ \\
\hline
\end{tabular}
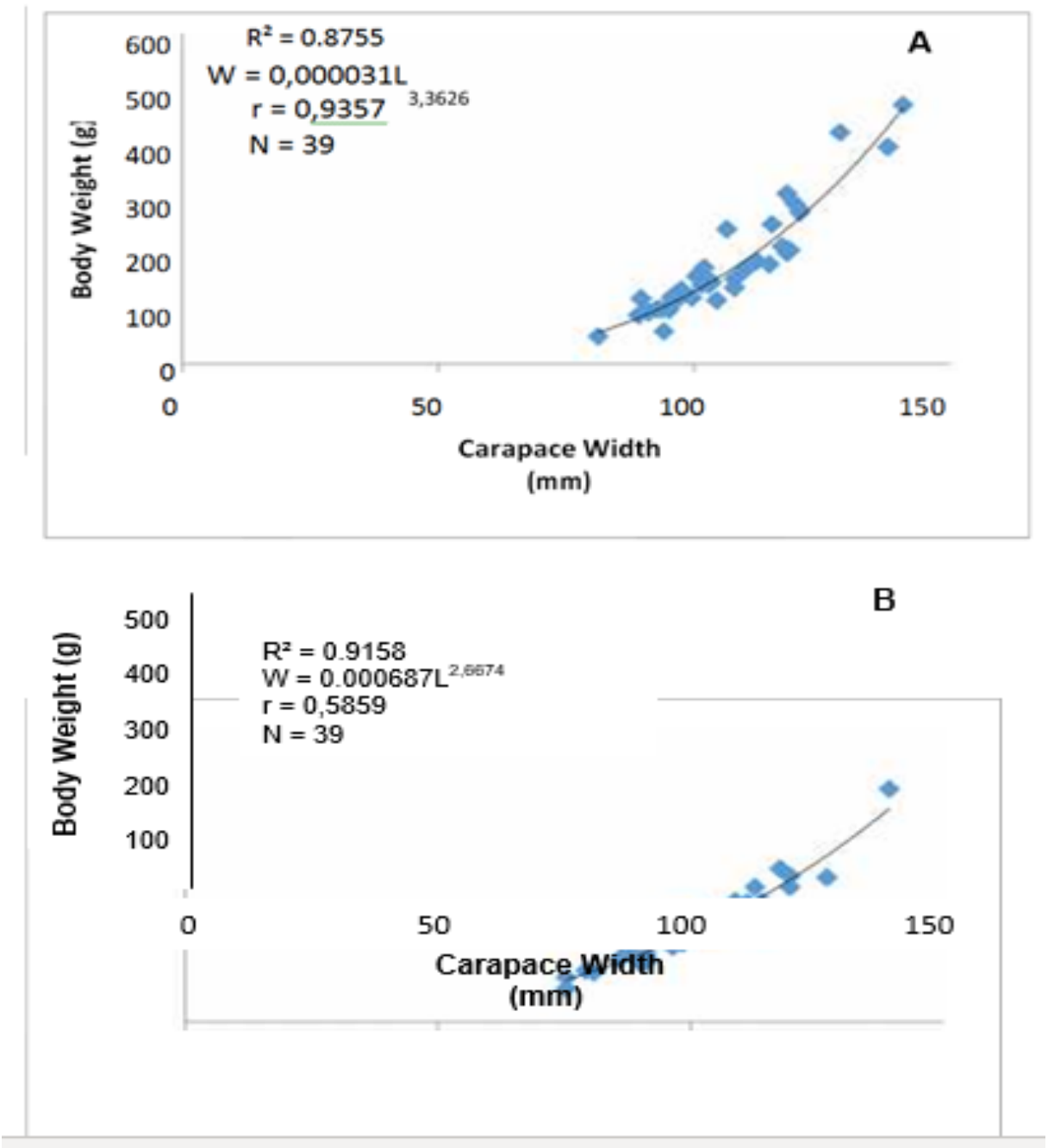

Figure 4: The correlation of carapace width - body weight of mangrove crab (Scylla serrata Forsskål, 1775) male (A) and female (B) in February in the coastal waters of Kuri Lompo and Maros estuary

Based on table 2, it was seen that male crabs in March had a larger number of 41, compared with female crabs by 17. $b$-value for male crabs is 3.5965 , while female crabs are 2.6506 . The result of t-test analysis showed that male crabs have allometric-positive growth type, the increase of weight 
is faster than the increase of carapace width, whereas female crabs have an isometric growth type, is the increase of carapace width is equal with body weight. The graph of the correlation of carapace width and body weight of male and female crabs is presented in figure 5.
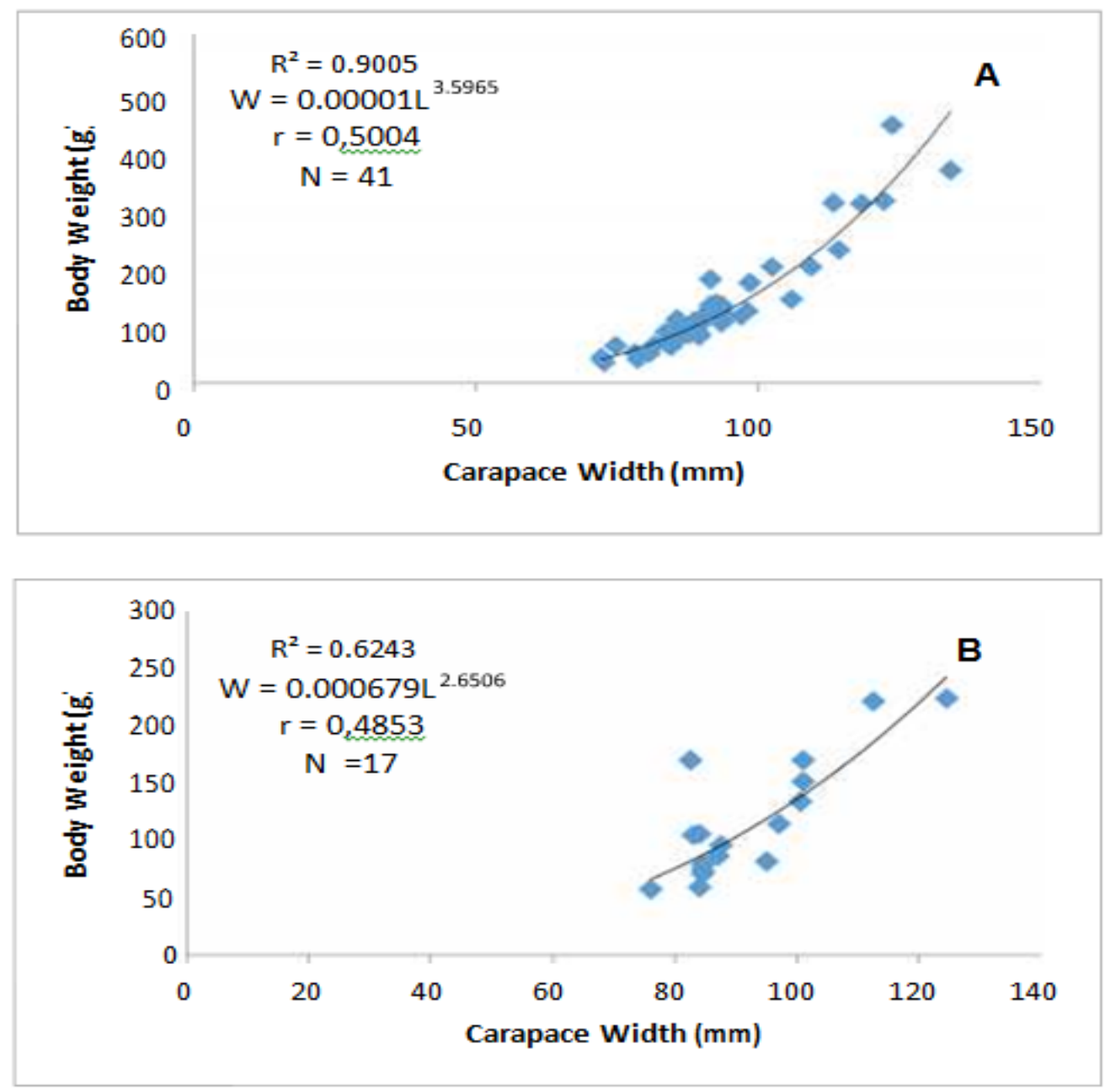

Figure 5: Correlation of carapace width - body weight of Mangrove Crab (Scylla serrata Forsskål, 1775) male (A) and female (B) in April in the coastal waters of Kuri Lompo to Maros estuary

The correlation coefficient ( $\mathrm{r}$ ) for the equation of male mangrove crab is 0.5004 and for the female is 0.4853 (Table 2). Values indicate there is a moderate correlation between the correlation of carapace width to body weight of male and female mangrove crabs. This is in accordance with the opinion of Andy Omar (2009) which states that if the value of correlation coefficient 0.40 to 0.69 indicates a moderate correlation. Based on the analysis of carapace width and body weight of mangrove crab, it is known that $b$ value in male mangrove crabs during is higher than in females. According to Wijaya et al. (2010), male mangrove crabs tend to be aggressive in finding food so that the energy gained for growth will be higher. Based on the analysis of carapace width to body weight of mangrove crab in the coastal waters of Kuri Lompo to Maros estuary in February showed the isometric growth type for male mangrove crabs and allometric-negative for female mangrove crabs. 
Isometric growth types in male mangrove crabs were also found in the research results of Thirunavukkarasu and Shanmugam (2011) in Parangipettai Waters, India. While, allometricnegative growth type in female mangrove crabs was also found in the research results of Asmara et al. (2011) in Segara Anakan Waters, Cilacap district, Central Java; Sentosa and Sham (2011) in Mayangan Waters, Subang, West Java; Mohapatra et al. (2010) in Chilika, India; Wijaya et al. (2010) in Mangrove National Park of Kutai, East Kutai district; Nur'aini (2016) in Delta Cimanuk Waters, Indramayu, West Java; and Khan and Mustaqeem (2013) on Karachi Waters, Pakistan. While, in March showed a allometric-positive growth type for male mangrove crabs and isometric for female mangrove crabs. An allometric-positive growth type in male mangrove crabs is also found in Mohapatra et al. (2010) in Chilika, India and Wijaya et al. (2010) in Mangrove National Park of Kutai, East Kutai district. While, the isometric growth type in female mangrove crabs was also found in the research results of Thirunavukkarasu and Shanmugam (2011) in Parangipettai Waters, India (Table 3). Different growth types of male and female mangrove crabs as shown in Table 3 is allegedly due to environmental differences, energy-use and food intake. According to Wijaya et al. (2010) female mangrove crab uses more food intake for molting and gonad maturation process (laying eggs). So the growth of female mangrove crab tends to be more towards the carapace width because the female crab will molting each will perform the process of copulation. While, on male crabs, molting is rare, so food intake tends to be used to lengthen and raise the claw that plays an important role in the marriage process. Rachmawati (2009) also said that factors affecting crustacean growth include 2 (two) factors, namely internal and external factors. Internal factors include size, gender, maturity level, and disability. While the external factors, include the availability of food, temperature, environment and parasites.

\subsection{Condition Factor}

The value of condition factor of crabs caught in the coastal waters of Kuri Lompo up to Maros estuary, based on observation time and sex can be seen in Table 4.

Table 4: Value of condition factor of mangrove crab (Scylla serrata Forsskål, 1775) in the coastal waters of Kuri Lompo up to Maros estuary

\begin{tabular}{|l|l|c|c|c|c|c|}
\hline $\begin{array}{l}\text { ObservationSex } \\
\text { time }\end{array}$ & $\begin{array}{c}\text { N= Total } \\
\text { organism }\end{array}$ & \multicolumn{2}{|c|}{ Ranges } & \multicolumn{2}{c|}{ Condition Factor } \\
\hline February & Male & 39 & $76.5-137$ & $60.84-489.37$ & $13.5895-$ & $17,0761 \pm$ \\
& & & & & 19.0316 & 2,8521 \\
\cline { 2 - 7 } & Female & 39 & $75-140$ & $53.57-$ & $0.3327-$ & $1,0057 \pm$ \\
& & & & 399.27 & 2.4797 & 0,3970 \\
\hline March & Male & 40 & $73-137$ & $58.70-485$ & $12.79-19.0$ & $16,2+1,97$ \\
\cline { 2 - 7 } & Female & 37 & $74-138$ & $53.57-483$ & $0.34-1.97$ & $1,13+0,67$ \\
\hline April & Male & 41 & $72.5-135$ & $54.13-$ & $0.3879-$ & $1,0681 \pm$ \\
& & & & 381.97 & 2.7375 & 0,6756 \\
\cline { 2 - 7 } & Female & 17 & $76-124.5$ & $57.17-$ & $13.0235-$ & $14,5626 \pm$ \\
& & & & 224.52 & 11.6345 & 4,7321 \\
\hline
\end{tabular}

Based on table 4, it can be seen that in February the average value of male mangrove crabs was greater than that of males, i.e for males of $17.0761 \pm 2.8521$ and for females of $1.0057 \pm 0.3970$, as well as in March, this is due to body weight of male mangrove crab larger than female mangrove 
crab. In April, the average value of female mangrove crabs was greater than that of males, i.e for females of $14.5626 \pm 4.7321$ and for males of $1.0681 \pm 0.6756$. This is due to body weight of female mangrove crab larger than male mangrove crab.

Based on the statistical test, the condition factor of male and female mangrove crabs in February obtained $t_{\text {count }}$ of 34.8515 and $t_{\text {table }}$ of 1.9917. This shows a significant difference between the condition factor of male and female mangrove crabs in February. The statistical test of the condition factor of male and female mangrove crabs in April obtained $t_{\text {count }}$ of 18.0405 and $t_{\text {table }}$ of 2.0032. This shows a significant difference between the condition factor of male and female mangrove crabs in April. For the analysis result of average value of mangrove crab condition factor in several research locations can be seen in Table 5.

Table 5: Value of condition factor of Scylla serrata in several research locations

\begin{tabular}{|c|c|c|c|c|}
\hline \multirow[t]{2}{*}{ Species } & \multicolumn{2}{|c|}{$\begin{array}{c}\text { Average Value of Condition } \\
\text { Factor }\end{array}$} & \multirow[t]{2}{*}{ Location } & \multirow[t]{2}{*}{ Reference } \\
\hline & Male & Female & & \\
\hline $\begin{array}{l}\text { Scylla } \\
\text { serrata }\end{array}$ & 22,37 & 22,5 & Bangladesh & Ali et al., 2004 \\
\hline $\begin{array}{l}\text { Scylla } \\
\text { serrata }\end{array}$ & 1,0333 & 1,0192 & $\begin{array}{l}\text { Segara Anakan Waters, Kab. } \\
\text { Cilacap, Jateng }\end{array}$ & $\begin{array}{l}\text { Asmara et al., } \\
2011\end{array}$ \\
\hline $\begin{array}{l}\text { Scylla } \\
\text { serrata }\end{array}$ & 0,09831 & 0,1712 & Karachi Waters, Pakistan & $\begin{array}{l}\text { Khan et al., } \\
2014\end{array}$ \\
\hline $\begin{array}{l}\text { Scylla } \\
\text { serrata }\end{array}$ & 0,0719 & 0,0671 & Chilika Waters, India & $\begin{array}{l}\text { Mohapatra et al., } \\
2010\end{array}$ \\
\hline $\begin{array}{l}\text { Scylla } \\
\text { serrata }\end{array}$ & 21,390 & 16,581 & $\begin{array}{l}\text { Pantai Mayangan Wates, Kab. } \\
\text { Subang, Jabar }\end{array}$ & $\begin{array}{l}\text { Sentosa dan } \\
\text { Syam, } 2011\end{array}$ \\
\hline $\begin{array}{l}\text { Scylla } \\
\text { serrata }\end{array}$ & 17,0761 & 1,0057 & Makassar Waters to Maros & $\begin{array}{l}\text { Suwarni \& } \\
\text { Yunus, } 2016\end{array}$ \\
\hline $\begin{array}{l}\text { Scylla } \\
\text { serrata }\end{array}$ & 1,0681 & 14,5626 & Makassar Waters to Maros & $\begin{array}{l}\text { Suwarni \& } \\
\text { Yunus, } 2016\end{array}$ \\
\hline
\end{tabular}

In Table 5, it is seen that in this research in February and March, the average value of male mangrove crabs is greater than that of female mangrove crabs. Similar results were also found by Ali et al. (2004) in Bangladesh; Asmara et al. (2011) in Segara Anakan waters of Cilacap district, Central Java; Mohapatra et al. (2010) in Chilika Waters, India; and Sentosa and Sham (2011) in Mayangan Waters, Subang district, West Java. While, in March found the average value of condition factor of female mangrove crab greater than male mangrove crab. Similar results were also found by Khan et al. (2014) in Karachi Waters, Pakistan. This is allegedly caused because the gonad weight of female mangrove crab is heavier than male crabs. According to Wijaya et al. (2010), male mangrove crabs tend to be aggressive in finding food so that the energy gained for growth will be higher. Rodriguez (1987) in de Araujo and de Lira (2012) said that the different value of condition factors in male and female crabs is allegedly to be influenced by nutritional factors, gonad maturity, recruitment time and selectivity of fishing gear. The value of condition factor is strongly influenced by external factors, i.e the environment and internal factors, i.e gonad development rate, growth rate, appetite and the number of parasites in the body. Season and number of population can also influence the value of condition factor on mangrove crab (Le Cren, 
1951; Rodriguez, 1987; Vazzoler, 1996; Froese, 2006; Pinheiro and Fiscarelli, 2009 in Khan et al., 2014).

\subsection{Abundance}

Abundance of mangrove crabs is more randomly distributed around the integrated mangrove ecosystem area of pond which includes the coastal waters of Kuri Lompo and estuary ecosystem of Maros river, and is evenly distributed at 0.005 ind. $/ \mathrm{m}^{2}$ (Table 6). This clarify the ecological nature of mangroves to environmental factors such as temperature, salinity, $\mathrm{pH}$, abundance of feed and organic material evenly and homogeneous in integrated development areas (silvofishery), and has the protection and buffer powers as ecological factor favored by organisms, crabs and shrimp than in other habitats.

Table 6: Abundance of Scylla serrata in Silvofishery development area of Kuri and estuary of

\begin{tabular}{|l|c|c|c|c|c|c|}
\hline Station (Development Area & \multicolumn{2}{|c|}{ February } & \multicolumn{2}{c|}{ March } & \multicolumn{2}{c|}{ April } \\
\cline { 2 - 8 } Silvofishery) & Male & Female & Male & Female & Male & Female \\
\hline - Kuri Lompo & 34 & 25 & 41 & 16 & 33 & 27 \\
- Maros Estuary & 29 & 32 & 31 & 29 & 17 & 41 \\
\hline Abundance & \multicolumn{2}{|c|}{120} & \multicolumn{2}{|c|}{117} & \multicolumn{2}{|c|}{118} \\
& \multicolumn{3}{|c|}{$(0,005 / \mathrm{m} 2)$} & $(0,0051 / \mathrm{m} 2)$ & $(0,0051 / \mathrm{m} 2)$ \\
\hline
\end{tabular}

Distribution analysis of chi-square (Richard and Marx, 1981) showed Scylla serrata is randomly distributed with relatively equal composition and amount of abundance at each specimen collection station. This shows the habitat of mangrove crabs in the integrated development areas of ponds and mangroves (silvofishery) is still quite stable to meet the ecological needs of these organisms. Based on the distribution of abundance, the habitat for Scylla serrata in the ecosystem of Kuri Lompo and Maros estuary has a close association with mangrove vegetation of Sonneratia, Rhizophora, Combretaceae, Meliaceae, Bruguiera, and Ceriops. While, ecological supporting factors in the association in the micro-habitat are temperature $24-29^{\circ} \mathrm{C}$, salinity $17-23 \%$, gravel sandy substrate with composition 3:2:1, $\mathrm{pH}$ 6.8-8.7 and brightness 0.90-1.20. Some group of crustaceous such as Panulirus and Penaeid as reference control from Scylla above, show a randomly distribution in sublitoral areas where habitats with ecological and aquatic qualities such as temperature, salinity, $\mathrm{pH}$, turbidity and feed distribution also homogeneously distributed, and this shows a common habitat association in a permanent area (Ludwig, 1988).

\section{Conclusion and Suggestion}

\subsection{Conclusion}

Based on result of research about the correlation of carapace width - weight, condition factor, and abundance of mangrove crabs Scylla serrata forsskål, 1775; in embankment lane silvofishery development area, Maros district can be concluded as follows:

1) The growth type in February for male mangrove crabs are isometric and female mangrove crabs are allometric-negative. While, in March for male mangrove crabs are allometricpositive, while the female mangrove crabs are isometric. 
2) The average value of the condition factor in February of male mangrove crabs is greater than the female mangrove crab. While in March, the average value of female mangrove crabs is greater than male mangrove crabs.

3) The habitat of mangrove crabs in the integrated development areas of ponds and mangroves (silvofishery) is still quite stable to meet the ecological needs of Scylla serrata. Based on the distribution of abundance, the habitat for Scylla serrata in the coastal waters of Kuri Lompo and estuary of Maros river has a close association with mangrove vegetation of Sonneratia, Rhizophora, Combretaceae, Meliaceae, Bruguiera, and Ceriops. While, the ecological supporting factors in the association in the micro-habitat are temperature 24$29^{\circ} \mathrm{C}$, salinity $17-23 \%$, and gravel sandy substrate with composition $3: 2: 1$, pH $6.8-8.7$ and brightness $0.90-1.20$.

\subsection{Suggestion}

Further research is needed with observation time, species and number of sample of mangrove crabs with various sizes, regarding biological aspects, both reproductive and population biology of mangrove crab. Not only on Scylla serrata but in all three types of other mangrove crabs to obtains more complete data and information.

\section{Acknowledgment}

Acknowledgments to Prof. Dr. Ir. Nurdin Abdullah, M.Sc., and Mrs. Ir. Liestiaty Fachrudin, M.Agr. Fish., as regent of Bantaeng and the head of the woman movers of Bantaeng Regency for financial aid and morale and material during this research

\section{References}

[1] Ali, M.Y., Kamal, D., Hossain, S.M.M., Azam, M.A., Sabbir, W., Murshida, A., Ahmed, B., and Azam, K. 2004. Biological Studies of The Mud Crab, Scylla serrata (Forskal) of The Sundarbans Mangrove Ecosystem in Khulma Region of Bangladesh. Pakistan Journal of Biological Sciences. 7 (11): $81-86$.

[2] Asmara H., Riani E., dan Susanto A. 2011. Analisis Beberapa Aspek Reproduksi Kepiting Bakau (Scylla serrata) di Perairan Segara Anakan, Kabupaten Cilacap, Jawa Tengah. Jurnal Matematika, Saint dan Teknologi. 12 (1): 33 - 35.

[3] de Araújo, M. S. L. C., and de Lira, J. J. P. R. 2012. Condition factor and Carapace Width versus Wet Weight Relationship in The Swimming Crab Callinectes danae Smith 1869 (Decapoda: Portunidae) at The Santa Cruz Channel, Pernambuco State, Brazil. Journal Nauplius 20 (1): 41 50.

[4] Khan, M. A. and Mustaqeem, J. 2013. Carapace Width Weight Relationships of Mud Crab Scylla serrata (Forsskal, 1775) from Karachi Coast. Canadian Journal of Pure \& Applied Science Vol. 7 No. 2: $2381-2383$.

[5] -------, 2014. Some Biological Aspects of The Portunid Crab Scylla serrata (Forsskål, 1775) from Coastal Waters of Karachi, Pakistan. International Journal of Biology and Biotechnology. 11 (2-3): $177-190$.

[6] Keenan, C. P., Davie, P. J., and D. L. Mann. 1998. A Revision of The Genus Scylla De Haan, 1833 (Crustacea: Decapoda: Brachyura: Portunidae). The Raffles Bulletin of Zoology. 46: 217 - 245. 
[7] Ludwig, J.A. and J.F. Reynold, 1988. Statistical Ecology. A Primer on Method and Computing. A Wiley-Interscience Publication. John Wiley and Sons. New York, Chichester, Brisbane, Toronto, Singapore.

[8] Mohapatra, A., Mohanty, R. K., Mohanty, S. K., and Dey, S. K. 2010. Carapace Width and Weight Relationships, Condition Factor, Relative Condition Facto and Gonado-Somatic Index (GSI) of Mud Crabs (Scylla spp.) from Chilika Lagoon, India. Indian Journal of Marine Sciences. 39 (1): $121-126$.

[9] Motoh, H. 1980. Field Guide for The Edible Crustacea of The Philippines. Southeast Asian Fisheries Development Center (Seafdec) Aquaculture Department, Iloilo, Philippines: 13 -14 .

[10] Richard, J. L. and Marx, M. L. 1981. An Introduction to Mathematical Statistics and Its Applications. Engelwood Cliffs, New Jersey: Prentice Hall, Inc.

[11] Sentosa, A. A., dan Syam, A. R. 2011. Sebaran Temporal Faktor Kondisi Kepiting Bakau (Scylla serrata) di Perairan Pantai Mayangan, Kabupaten Subang, Jawa Barat. Jurnal Perikanan (J. Fish. Sci) XIII (1): $35-39$.

[12] Thirunavukkarasu, N., and Shanmugam, A. 2011. Length Weight and Width- Weight Relationships of Mud Crab Scylla tranquebarica (Fabricius, 1798). European Journal of Applied Sciences 3 (2): $67-70$.

[13] Wijaya, N. I., Yulianda F., Boer M., dan Juwana S. 2010. Biologi Populasi Kepiting Bakau (Scylla serrata F.) di Habitat Mangrove Taman Nasional Kutai, Kabupaten Kutai Timur. Jurnal Oseanologi dan Limnologi di Indonesia. 36 (3): 443 - 461.

*Corresponding author.

E-mail address: bu_yun@fisheries.unhas.ac.id 